Int. J. Dev. Biol. 50: 439-449 (2006)

doi: $10.1387 / \mathrm{ijdb} .052127 \mathrm{sb}$

Essay

\title{
August Rauber (1841-1917): from the primitive streak to Cellularmechanik
}

\author{
SABINE BRAUCKMANN* \\ Konrad Lorenz Institute for Evolution and Cognition Research, Altenberg, Austria and Department of Pediatrics, University of Utah \\ School of Medicine, Salt Lake City, Utah, USA
}

\begin{abstract}
In the early 19th century Karl Ernst von Baer initiated a new research program searching for the mechanisms by which an egg transforms itself into an embryo. August Rauber (1841-1917) took up this challenge. He considered the phylogenetic principle as the right tool to explain the similitude of embryogenetic processes. In extending Baer's approach, he combined comparative embryology and histology in his studies of avian and mammalian embryos. His earlier work demonstrated that the two-layered chick embryo is a modified gastrula and not a "disc" as Wilhelm His had claimed. From the 1880s onwards, he concentrated on the issue of how the development of germ layers is related to tissue differentiation. To address this, he studied the blastopore, epiblast, primitive streak, teratology and the relative importance of nucleus and cytoplasm in heredity. This paper reconstructs some of Rauber's work and concludes that his observations and reflections constituted a new approach combining embryology and histology with "phylogenetic" reasoning.
\end{abstract}

KEY WORDS: Rauber, von Baer, blastodisc, primitive streak, cell mechanics, homology

\section{Introduction}

The University of Tartu (Dorpat) in Estonia, founded by the Swedish king Gustav II Adolf in 1632, has the distinction of being an organizing center for the new approach of comparative embryology. It was here that Karl Ernst von Baer (1792-1876) and Christian Pander (1794-1865) started their medical studies, where Heinrich Rathke (1793-1860) and Carl Boguslaw Reichert (18111893), a student of von Baer, taught embryology and anatomy and August Rauber (1841-1911) headed the Institute of Anatomy, Histology and Embryology for nearly 30 years. Unlike the many treatises on von Baer and some new studies on Pander (Churchill 1991; Schmidt 2005), most of the work on Rauber's life and science is published either in German or Estonian. The biologist behind "Rauber's sickle" of the chick embryo and "Rauber's layer" of the mammalian blastocyst was one of the first embryologists who attempted to explain embryogenesis by uniting a comparative embryological approach to a biomechanical concept of growth and differentiation. Further, Rauber played a determining part in the history of embryology, in particular in the relationship between experimental and phylogenetic embryology at the end of the 19th century. His work is also important for current research as it concerns the origin of central topics in developmental biology, e.g. embryonic cell movement and folding.
With his two volumes of Entwickelungsgeschichte der Thiere von Baer set the stage for comparative morphology by searching for the mechanisms that transform an egg into an embryo (von Baer 1828, 1837). His first tentative explanation related these mechanisms to a kind of electrochemical potency being effected by and, at the same time, effecting a disparity of yolk inside the egg. In the description of chick embryogenesis Baer meticulously specified how the albumen moves along the vertical (main) axis, also called the chalazal axis, to the acute or pointed egg pole. In the embryo that is developing above this axis, newly added substances concentrate on the left side instead of migrating to the right side (acute embryo pole). To explain the dynamics of these movements, he utilized the new discovery of electromagnetism (Baer 1828; Tammiksaar and Brauckmann 2004). Moreover, he intended his 'observation and reflection' on embryogenesis to enhance the comparative approach of animal classification by demonstrating vertebrate affinities.

Rauber, an anatomist of nearly mathematical conclusiveness and an experimenter of exceptional skill, took up this challenge when studying the general pattern of embryogenesis. His point of departure was to adopt Baer's conception of the vesicle as the basic form of embryonic life. In extending Baer's approach he combined comparative embryology and histology in his studies of avian and mammalian development. Rauber's first work demon-

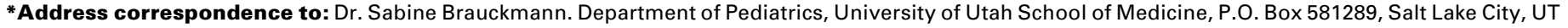
84158, USA. Fax: +1-801-587-4717. e-mail: u0386312@utah.edu
} 
strated that the two-layered chick embryo is a modified gastrula and not a disc-like structure as Wilhelm His (1831-1904) claimed. Although an important discovery, it meant a long detour in Rauber's career as the powerful His resented this contradiction. In further studies Rauber elucidated the importance of the posterior marginal zone for the primordial embryonic anlagen of vertebrates.

From the 1880s he shifted his focus to the issue of how cell specificities push the dynamics of gastrulation; this time he carried on the research program of Robert Remak (1815-1865), applying the biomechanical approach of Rudolf Hermann Lotze (1817-1881). For this work on gastrulation, he studied the formation and histology of the blastopore, epiblast and primitive streak. Rauber's objective was to explore whether morphogenetic changes are produced by a disparity of cell growth, or whether they are purely geometrical functions set into motion by law-like growth relations. As a first answer he formulated a Cellularmechanik aiming at explaining these mechanisms, including the hereditary factors, which inform the zygote to form an embryo (Rauber 1880: 2, 22).

The following paragraphs explore Rauber' studies of the formation of the primitive streak in chick embryos and his ideas on how to explain causally a general mechanism of embryonic patterning. Further, I will introduce his Cellularmechanik which studied cell specification during gastrulation and briefly analyze its relevance to the germ layer theory. The essay will finish with a return to Baer's views on the claimed homology between Ascidians and vertebrates and will discuss how Rauber answered the question of whether we once were animals that walked on their back. My objectives here are (1) to present Rauber's "observation and reflection" as a new approach combining embryology and histology with "phylogenetic" reasoning and (2) to place his work in the context of the biological knowledge of the late 19th century.

Before introducing Rauber's work in greater detail, I have to say, at least a few words, about the controversy between $\mathrm{His}$ and Rauber. Although Rauber's biography is known (Lubosch 1924; Kogermann-Lepp 1991; Pawlow 1991; Aunapuu et al., 2005), the details of the dispute are not yet studied carefully in the context of comparative embryology of the 19th century.

\section{Biographical sketch}

August Rauber was born in Obermoschel (Bavarian Palatinate) on March 9, 1841 as the third son of a bailiff of humble origins; his mother's Alsatian family descended from chancellors of the university of Strasbourg. As a boy he liked to vivisect mice and to pore over in the internal organs. In 1851 he attended the grammar school in Neustadt where he was taught geometry, arithmetics, physics, natural history, drawing and modeling, French and English. Four years later he attended the humanistic Gymnasium in Speyer and finished with a university-entrance diploma in 1859. As his father urged him to study law, Rauber went to the University of Munich to become a lawyer. Already in his first year Rauber also attended courses and lectures of medicine, as Goethe had done in Strasbourg, and natural sciences and continued this strenuous program of double-studies during the following year. In the sec-

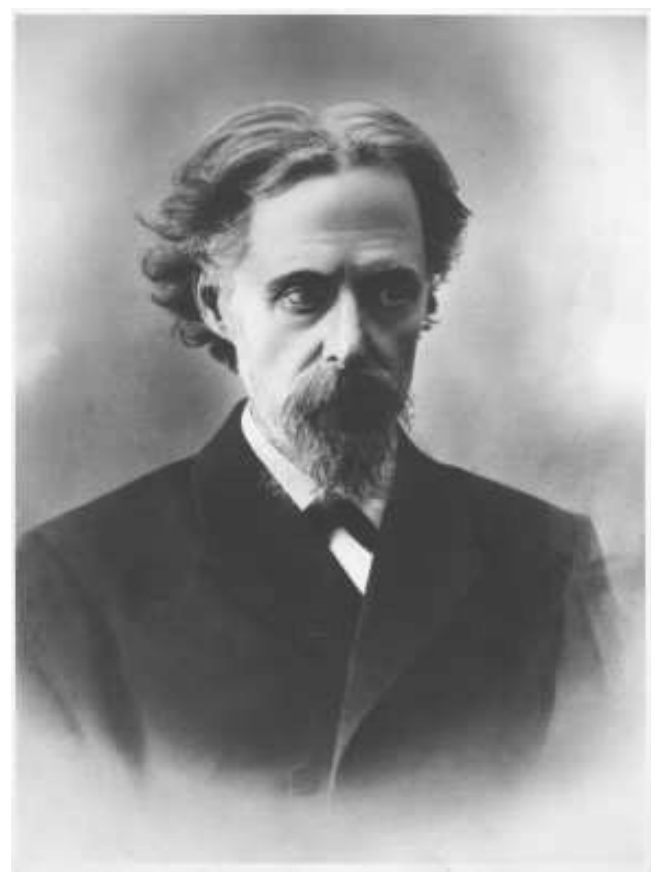

Fig. 1. August Rauber, ca. 1885. Courtesy of University of Tartu Medical Museum.

ond year he passed the clinical intermediate examination, without having missed any lectures for his study of law.

Among his anatomy teachers were such luminaries as Theodor Bischoff (1807-1882) and Nikolaus Rüdinger (1832-1896) who used photography for anatomical diagnoses. Bischoff, a student of Johannes Müller (1801-1858) taught developmental history and demonstrated embryogenesis with a leather model displaying a mammalian embryo with an open neural tube. From 1864 to 1866 Rauber was the assistant preparator in Rüdinger's pathology institute and finished his medical studies in 1865. He immediately left Munich for Vienna, then one of the most famous medical schools in Europe where at that time the histologist Josef Oellacher (1804-1880) studied the developmental history of teleosts.

Rauber qualified as a professor with his monograph on the ganglia of the upper arm and thigh. During the German-French War of $1870 / 71$ he served as military surgeon and utilized his experiences with bullet wounds to investigate the stability and elasticity of bone (Rauber $1876 \mathrm{~g}$ ). After his release from military service in 1872, Wilhelm His offered him the position of assistant professor in his anatomical institute at the University of Basle, which Rauber accepted at once. At Basle he lectured on the anatomy and regeneration of the nervous system of humans and animals. One year later His was promoted to the University of Leipzig and urged Rauber to follow him as prosector and extraordinary professor. However, circumstances brought the Leipzig episode to a quick and grievious end for Rauber.

His' idea when employing Rauber as prosector was to promote him in the near future to the chair of topological anatomy. Alas, the University of Leipzig did not follow His' proposal to install Rauber 
as professor, but appointed Wilhelm Christian Braune (18311892). Apparently, also Rauber hoped to be offered such a position since he was convinced that gross anatomy at the University of Leipzig owed him the best it could offer. At the same time the relationship between His and his prosector worsened when Rauber argued that the study of developmental history had to focus on homologies between different species and on the issue which structures develop from each other. In short, he demanded for the application of phylogenetic reasoning in sensu Haeckel to embryogenesis. To make things worse, Rauber was not shy to speak his mind about it, which for His, the patrician of Basle, was utterly intolerable (Lubosch 1924: 135).

After his public dispute with His on chick embryology, Rauber found himself abandoned by his colleagues in Leipzig and peers in Anatomy. On June 2, 1875 Rauber stepped down from the prosectorate, but continued his lectures without a salary at the Anatomical Institute. His academic career stagnated for 10 years during which he partly experimented in his own apartment shared with his two unmarried sisters and partly at the laboratory of his friend Robert Sachsse (1840-1895) who investigated the phytochemistry of plants at the Agricultural Institute in Leipzig. Although working as a hermit, Rauber's retreat yielded fruits in numerous articles and monographs on the blastopore, the primitive streak, teratology, experimental morphology and paleontology. During that time he also prepared the first draft of the famous textbook of human anatomy published for the first time in 1886the Rauber/Kopschis still a classical textbook of human anatomy (Rauber and Kopsch 1998).

At that time German universities offered several chairs at medical institutes, Rauber, however, who probably was one of the best anatomists of his time, was always passed over. When the University of Dorpat wanted to appoint a professor for Anatomy in 1885, Carl von Kupffer (1829-1902) successfully supported Rauber and in 1886 Rauber was appointed professor of anatomy, histology and embryology at Dorpat (Pawlow 1991:592; Aunapuu et al., 2005: 418-419). Among his colleagues at that university

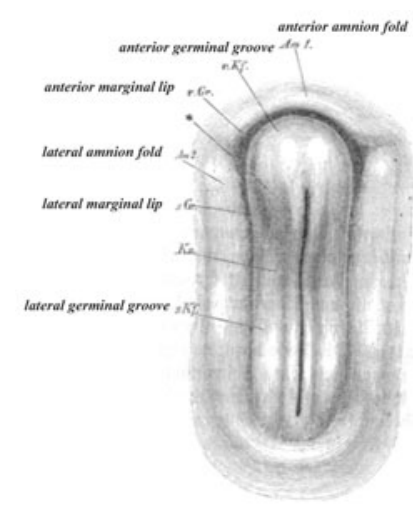

A

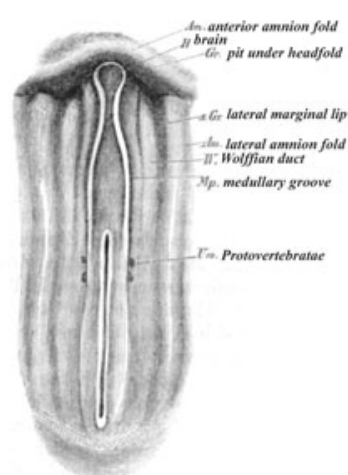

B
Fig. 2. The Chick Embryo. (A) 18 hours, dorsal view; Am 1, 2, notochord; v. and s. Kf, perinodal neural plate; $v$. and s. Gr, neural groove; * (description missing in original); $K z$ (description missing in original). (B) 12 hours, dorsal view; Am, amnion fold; $H$, headfold; Gr, neural groove; s. Gr, lateral neural groove; Am, amnion fold; W, neural plate; $M p$, neural fold; UW, somites. (C) Slashed rubber tube with convex folding (from His 1875: 16, 98, Figs. 14-15, 88 therein. Courtesy of John M. Opitz Library).

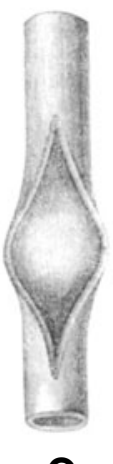

c were the physiologist Alexander Schmidt (1831-1894), the embryologist Dietrich Barfurth (1849-1927), the gynaecologist Heinrich Max Runge (1849-1909) and the psychiatrist Emil Kraepelin (1840-1926). When Rauber retired in the fall semester 1911, he also resigned as head of the Anatomical Institute and never entered the Anatomical Theater anymore (which celebrated its bicentennial in 2005).

In Dorpat Rauber continued the reclusive life he had lived in Leipzig. In the first years he kept company with some of his colleagues and participated in Dorpat's social life. However, when he married his Estonian housekeeper, he became a social outcast (cf. Kroos 1994). To compensate for his secluded life since the 1890s, Rauber engaged in charity events playing the violin and giving popular lectures to wider audiences about gender issues such as polygamy, felony and women emancipation. When World War I broke out in 1914, his wife and son Stephan were deported to Wologda, far north in the Russian Empire causing Rauber to close himself up completely. During the winter of 1916 he was very often bed-ridden, but refused any medical help. On February 6, 1917 August Rauber died in Dorpat and was buried under great participation of the Russian studentship. One week later the Russian Revolution broke out and his wife and son were able to return to Dorpat.

\section{The controversy on disc and gastrula}

In his rectorate lecture, His, who dedicated his treatise on chick development to von Baer, promoted a mechanical theory of embryogenesis seeking the proximate causes by which one stage of development transformed itself into the next (epigenesis). He detected these causes in the forces set up by differential growth (His 1870). His based his theory of morphogenesis on von Baer's question for the law of growth and baptized it Bildungsmechanik (mechanics of formation) (His 1868). Mechanics of formation here meant that an embryo develops in the mode it does because its body behaves like an elastic plate being unevenly stretched. Such a plate folds when cells grow and/or differentiate and His' new idea was to explain the folding by geological mechanisms, e.g. a kind of tectonics and to visualize it by material models made of leather, paper and rubber (His 1875; Fig. 2 therein).

To elucidate the uneven growth of such a plate, the physicist and mathematician Eduard Hagenbach-Bischoff (1833-1910) supplied His with several geometric equations for the monograph on chick development. His used these equations to causally relate the folding mechanisms to the embryo's asymmetrical growth and then concluded that the basic plan of the embryonic body and the organs develops in a manner similar to the deviating and folding of a leather strip. The observation, backed by histological staining of numerous microtome slices showed that the chick embryo exhibits a disc-like structure (His 1875: 17). His colleagues credited him as an ingenious master in handling this instrument (microtome) that he himself had invented (cf. Hopwood 199: 477-78). Over his scientific life His now elaborated, corrected and specified this program to finally com- 
pressing it to the simple statement: "Morphogenesis shapes the anlagen by embryonic growth and the potency of an embryo is a function of space" (His 1874: 153). In a way this statement anticipates the harmonious equipotential system of Hans Driesch (1867-1941) and/or the notion of the morphogenetic field of Alexander G. Gurwitsch (1874-1954) (cf. Mocek 1998; Gilbert et al., 1996).

However, His rejected the idea of explaining development on the basis of phylogenetic reasoning, as Haeckel demanded, since he thought that such a phylogenetic approach would merely interpret historical events instead of explaining the mechanisms of development (cf. Nyhart 1995). His' speech set off the battle over the crucial issue as to whether causation meant construing embryogenesis by the mechanical forces of pressure and tension which could be studied experimentally, or by deducing homologous shapes that had been formed during evolutionary time. By the end of the 1870s, this battle had escalated into an 'acrimonious controversy' (Hopwood 1999: 468).

Enter August Rauber. In summer 1874 Rauber, who then worked as prosector in His' Institute of Anatomy at the University of Leipzig, studied two newly fertilized eggs in the chick oviduct. He observed how the dorsal part of a far-developed blastodisc attenuated to a one-layer membrane of flattened cells, whereas the large cells of the marginal zone lie upon the yolk wall. From this marginal zone a cell layer splits off from the ectoderm and extends above the blastocoel. In following Alexander Goette's (18401922) and Pander's idea that foldings of the blastocoel shape the animal body (Goette 1875; Pander 1817; cf. Schmitt 2005), Rauber assumed that the blastocoel could have emerged by a centripetal excrescence from the medial part of the marginal zone where the primary germ layers differentiate by delaminating from one another (Rauber 1875b: 52). His microscopic observations demonstrated to Rauber that the chick embryo develops as a flat oval vesicle, the dorsal roof forming the ectoderm and the cells beneath the ventral cavity developing into the endoderm.

His and Rauber had their clash coram publico during a meeting of the Naturforschende Gesellschaft zu Leipzig on Friday, November 27, 1874. As His was rather cross with Rauber's discovery of the gastrula-like shape of the chick blastodisc, he most vehemently refuted Rauber's analyses of chick embryogenesis and teleost development, the other favorite experimental

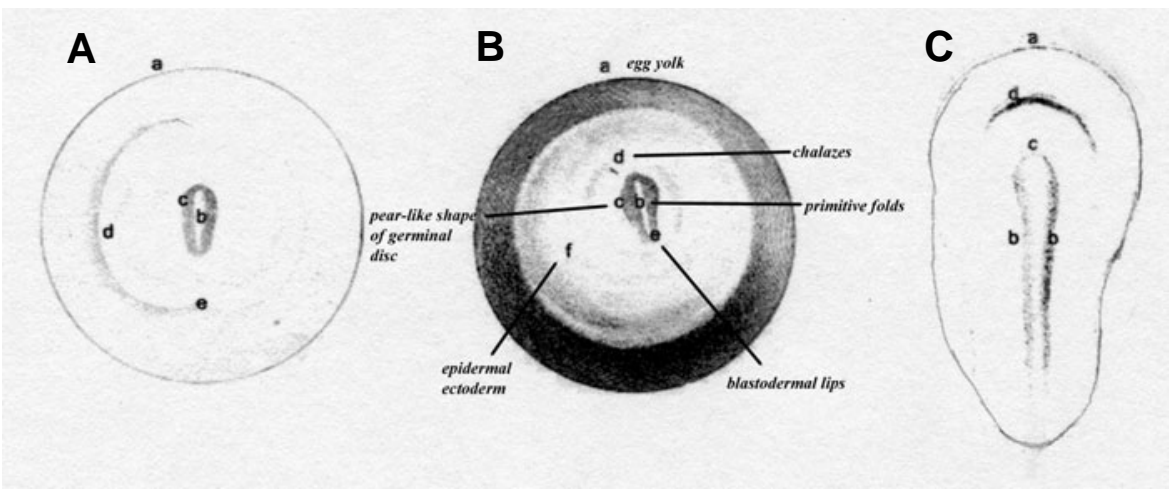

Fig. 3. Chick embryo of $\mathbf{1 6}$ hours. (A) $a$, anterior margin of blastoderm; $b$, medullary grooves; c, Hensen's node; d, lateral marginal zone; e, posterior marginal zone. (B) Dorsal view; d, germ cell crescent (hypoblast); $f$, area opaca. (C) a, anterior margin of area pellucida (from Pander 1817, Table I, Figs. 4-5, Table II, Fig. 2 therein. Courtesy of John M. Opitz Library). animal of His' program. His had already endured a vicious dispute with Ernst Haeckel and Carl Gegenbaur on the issue whether phylogenetic reasoning, or folding models of leather and paper would best explain the mechanism of embryogenesis. Two weeks later, His published a harsh comment on Rauber's observation in referring to the French zoologist Dominique-Auguste Lereboullet (1804-1865) who already had described the vesicle-like shape of the crayfish embryo. Thus, he denounced Rauber's discovery as a follow-up of a predecessors work and, by it, ingeniously sidestepped the issue of the 'real' shape of a chick embryo. Otherwise, he repeated his erroneous observations that the ventral layer sprouts cilia-like from the originally one-layered blastodisc and that the primordial anlagen develop an annulus and not a vesicle (His 1875). His' strong belief in mechanics forced him to think of microtubules (cilia) as the motile force in cleavage dynamics.

Rauber was not yielding to His' correction on any point, nor did he accept the critique of his peer. To aggavate matters, Rauber then published his own critique showing that His did not mention Pander as the 'father' of the folding principle (Rauber 1876d, $1876 \mathrm{e})$. Further, he stated that the large cells of the blastoporal lips fuse ectoderm and endoderm and that the mesoderm which exists before the formation of the primitive streak develops such that the cells appear to arrive at the developing mesoderm from the ventral side of the primitive groove (Rauber 1875a: 68). Rauber went on to state that the marginal zone of later developmental stages, as depicted in His' flat images (His 1877) appeared to be an artefact as the histological figures did not show the specificities of the cell structure (cell skeleton). He, therefore, claimed His' figures missed all traces of nuclei, nucleoli, cell membranes and part of the protoplasm. Moreover, Rauber contended that His had misconceived the marginal zone as white yolk (albumen), realiter a nutritional factor, which His called a parablastic substance (Rauber 1877a: 44). The 'archiblast-parablast' theory that interpreted His' observations of teleostan development claimed that the three germ alyers (archiblast) generate the whole embryo, except blood vessels and connective tissue. The latter are provided by the 'parablastic' substance of the white yolk, in realiter the marginal zone (Oppenheimer 1940: 6). Rauber lucidly demonstrated that His was a victim of his erroneous beliefs in the Parablast theory, an optical delusion. As His further mistook the marginal lips as the marginal zone, Rauber reasonably doubted that His had observed the marginal zone of the blastodisc at all.

Concerning the mechanical program of embryogenesis that His propagated against the Haeckel group in Jena, Rauber credited Lotze for having introduced the causal-analytical method of developmental mechanics into embryology. As of that time Rauber referred to Lotze's Mechanik von der Gestaltbildung (mechanics of morphogenesis) instead of His' Bildungsmechanik(Lotze 1885: 192). Lotze also anticipated the importance of an asymmetrical growth in dorso-ventral direction when arguing that organic forms display a kind of (molecular) particle dynamics affecting differentiating cells with an unequal impetus (cf. Rauber 1880, 1883).

Another more controversial approach to 


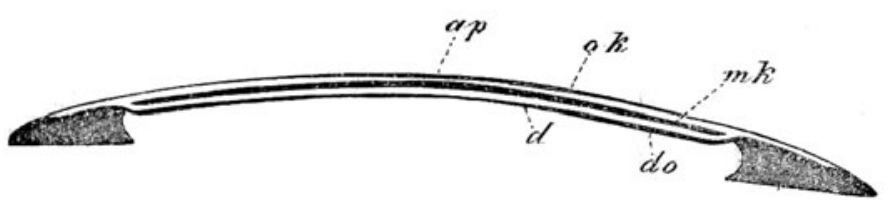

Fig. 4. Vertical section of chick blastoderm (after Remak). ap, primitive streak; ok, ectoderm; do, endodermal margins showing the area opaca; $m k$, mesoderm; $d$, thinner part of endoderm, or epithel; $d$, parts of free yolk (from Kölliker 1861: 43, Fig. 15.2 therein. Courtesy of John M. Opitz Library).

the enigma of gastrulation was His' concrescence theory which claimed that the medullary (neural) layer is pushed from the equatorial to the ventral end of the egg by folding down on both sides. The two discs then fuse with each other at the bottom in the median plane in a cephalo-caudal direction (Rauber 1875b). His was mistaken in concluding that the longitudinal axis develops by closure of the blastopore lips, an error Rauber avoided (Rauber 1883a). Nevertheless, the issue of concrescence was not solved until 1929, when Walter Vogt published his seminal work on amphibian gastrulation, with the vital staining method demonstrating that the cells from the surface migrate through the blastopore lip to become specific endodermal and mesodermal precursors (Brauckmann and Gilbert 2004: 10).

The whole controversy between Rauber and His depended on accurate observation, its visualization and representation. In this, Rauber was probably the keener observer, even if he sometimes overinterpreted what he saw (Fig. 5). When looking closely to Fig. 2 and its legends, one recognizes that the embryonic structures His described are artificial images of chick embryos of stages 4 and 7 (Hamburger and Hamilton 1951). Another point for the greater accuracy of Rauber's observations are his illustrations of frog embryos (Rauber 1883a). He was one of the few embryologists (the other major one being Goette) who carefully observed that the cleaving egg was not a uniformly symmetrical and more or less quadrangular body as wrongly depicted in textbooks for decades (Rauber 1883a: 273; Thompson 1942: 490, 604-605).

\section{Primitive streak and primitive groove}

Pander appears to have observed the primitive streak as early as 1817 , but did not mention it explicitly as his description of the drawings of Fig. 3 demonstrate (Pander 1817, Table I, Figs. 4,5, Table II and Fig. 2 therein). Later von Baer corrected Pander's erroneous terminology and designated Pander's 'primitive folds' as medullary plates and the blastodermal fold as primitive streak (von Baer 1828: 13-14; Fig. 3C therein). Further, he described in detail how embryogenesis starts at the primitive streak that lies in the middle of the ventral side of the embryo (von Baer 1828: 245). In following Remak's investigation of vertebrate development Rudolf Albert von Kölliker (18171905) depicted how the primitive streak forms by the growing together of ectoderm and endoderm in a small spot that emerges horizontally to the longitudinal egg axis. Whereas the pellucid area forms an oval structure and the embryonic anlage merges into a longish shape, the primitive groove develops by thickening of the lateral sides of the primitive streak (Kölliker 1861: 43-44, Fig. 4 therein).

When carefully investigating chick embryogenesis and, in particular, the primitive streak in the 1870s, Rauber hoped that a concise study of the formation of the germ layers would unravel whether the blastocoel existed alongside Baer's (subgerminal) cavity. He utilized the primitive streak since it was well-suited for a comparison of the developmental history of different species (Rauber 1876b). Thus, he took up the Baerian research program that demanded a classification of animal species by comparing developmental stages. As model organism he chose the chick and focused on its early developmental stages, in particular, the formation of the posterior marginal zone that forms the equator of the germ vesicle (Rauber 1875b). Although the chick had been studied extensively since Malpighi, the patterning of blastulae and gastrulae were still terra incognita, despite work by Jean-Jacques Coste (1807-1873), Oellacher and Goette who worked mainly with frogs. Rauber started his investigations with a hypothesis, namely that the medullary ridge attaches to the blastopore. Otherwise, he could not envision the formation of the primordial anlagen in the posterior region of the blastodisc.

Goette had observed previously that the chick blastodisc had a thickened marginal zone that protrudes over the future epiblast and disappears into the anterior half of the embryo while its cells migrate into the blastocoel to form the endoderm (Goette 1875). Rauber challenged Goette's analysis when observing that the medullary ridges does not disappear but follows the potruding of the embryo above the yolk (first embryonic anlage). Following the median line of the marginal zone a multi-layered group of cells extended from the upper layer to the vegetal pole where it forms the one-cell-layered endoderm. These large spherical cells then penetrate to the internal surface of the albumen (Rauber 1875b: 50). The subgerminal cavity, between the endoderm and the yolk,

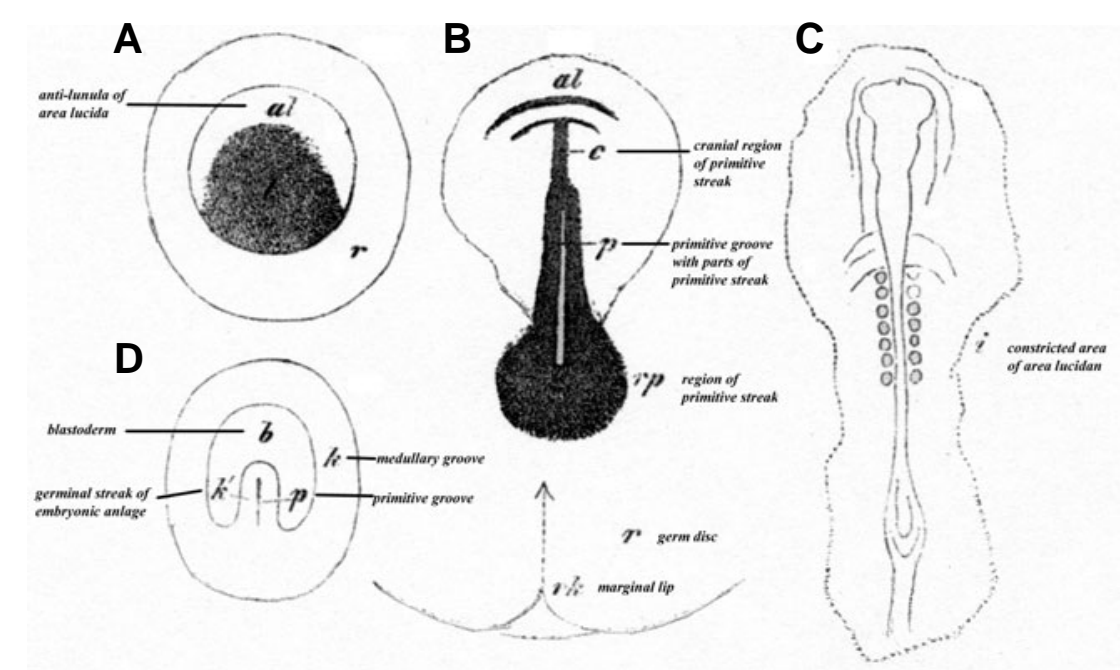

Fig. 5. Chick blastodics. (A) 6 hours; al, area pellucida; r, germ wall. (B) Area lucida, 15 hours; $c$, head process (notochord); $p$, primitive groove with parts of the primitive streak; $r p$, caudal end of the primitive streak; the arrow scheme depicts the relation to primitive groove. (C) Area lucida, 35 hours; i, area vasculosa (area opaca). (D) Chick scheme; b, blastoderm, p, primitive streak; k, area opaca; k', epiblast (from Rauber 1877a: 37, Figs. 24 27 therein). 

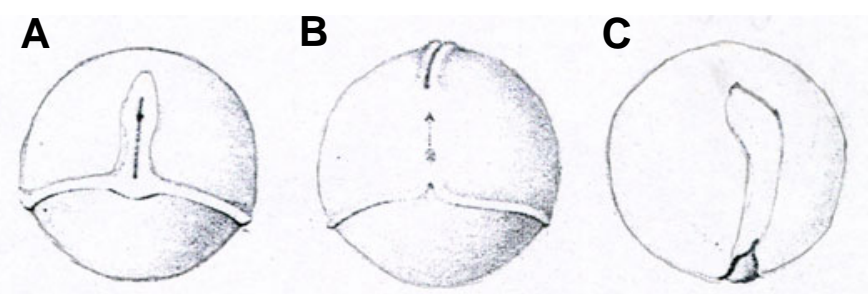

Fig. 6. Comparison of gastrulae. (A) Chick gastrula with blastopore and primitive groove. (B) Blastopore and primitive groove of a teleost. (C) Blastopore and primitive groove of a frog (from Rauber 1876a, Table XXXVII, Figs. 9-11 therein).

forms from a cellular duct-like structure which precedes the division of layers and develops from a central hollow that Rauber described as the primordial 'vegetal cavity' (Saftraum) for nutritional reasons (Rauber 1877a: 1). Thus, the pre-stage of the primitive streak is a lunula-shaped structure that merges with the posterior marginal zone and the primitive streak later forms along the anterior-posterior axis with the mesoderm attaching on both sides.

The drawings in Fig. 5 illustrate how the posterior edge of the cresent adjoins to the curvature of the marginal zone. Once the primitive streak develops, its marginal lips shape up from the abutting parts of the marginal zone. The comparison of figures $B$ and $C$ caused Rauber to call the lunula and the primitive streak of the area lucida the 'anterior embryonic anlage' that gradually attaches dorsally (Rauber 1877a: 23). When he realized the 'causal' relationship between the formation of the primitive streak and primitive groove, Rauber elucidated the marginal position of both structures by relating the formation of both structures to that of the amphibian blastoporal lips. Figure 6 that depicts highly idealized drawings with the camera lucida compares the blastopore and primitive groove of a chick, a teleost and a frog in which Rusconi's aperture transforms anterior to a narrow split that merges into the primitive groove. Rauber utilized the drawings to support his 'morphogenetic' principle, namely that the vertebrate blastopore (epi)genetically bears on the primitive streak and medullary grooves and, conversely, the blastoporal lips are (epi)genetically homologous to the primitive streak. For, the primitive groove descends from the blastopore and the primitive streak stems from the blastoporal lips. This mode of vertebrate development Rauber called 'stomatogenic' as it starts as a mouthlike structure, i.e. the blastopore (Rauber 1877a: III-IV).

Here Rauber also alluded to von Baer who described the primitive groove and streak when observing the 14th and 15th hour of fertilization. Von Baer noticed how a midline streak appeared in the area pellucida consisting of an accummulation of globules. Both agreed that at the sides of the medullary grooves emerged the primitive streak (Baer 1828: 222, 245; Rauber 1877a: 24). Rauber concluded that the primitive streak is, although a transient structure, the most important part of the primordial embryonic anlagen(1876a, 1877a). Indeed, the lunulashaped region of the epiblast giving rise to the primitive streak is still referred to as 'Rauber's sickle' (Rauber 1875b, 1876a; Callebaut and Van Nueten 1994). Most recent data corroborate Rauber's conclusion when relating 'Rauber's sickle' to the gastrulation organizer of the avian blastoderm (Callebaut 2005: 1203; cf. Lawson and Schoenwolf 2003). In addition, the work on avian and teleost embryogenesis that Rauber conducted over nearly a decade, demonstrated further how layers form, split and merge again. They also represented the data which he relied on when formulating his cellular mechanics (cf. below).

Independently of Rauber, Francis M. Balfour (1851-1882) pored over the formation of the primitive groove and its relation to the blastoderm. When reporting Lankester's work on Loligo Balfour stated that the development of chick mesoderm to that of the squid appears to proceed in the same manner (Balfour 1873a: 272, 1885: 152; cf. Lankester 1873). In his sections of stained chick embryos he further confirmed the 'perfectly accurate' observation of the German anatomist Emil Dursy (1828-1878) who had shown that the primitive groove is a temporary structure (Balfour 1873b: 276; cf. Dursy 1866). However, Balfour did not observe any relationship between the formation of the primitive groove and the medullary grooves as both arise in different regions of the blastoderm (1873b: 279; cf. Fig. 7 therein). Therefore, he concluded that primitive streak and medullary grooves arise completely independent from each other. In supposing that the primitive streak might be a remnant of an ancestral form, e.g. a trace of the involution of the ectoderm forming the endoderm in lower animals, he denied the primitive streak 'any function whatever' (Balfour 1873b: 280).

In his Comparative Embryology Balfour, now an experienced and distinguished embryologist with a superb knowledge of Selachian embryogenesis, acknowledged, in referring to Kölliker, the 'essential connection between the primitive streak and the formation of the mesoblast' (Balfour 1885: 150; cf. Kölliker 1861). However, although he now conceded that there might be a correspondence between the avian primitive streak and Selachian blastoporal lips, he disproved any 'genetic relation between

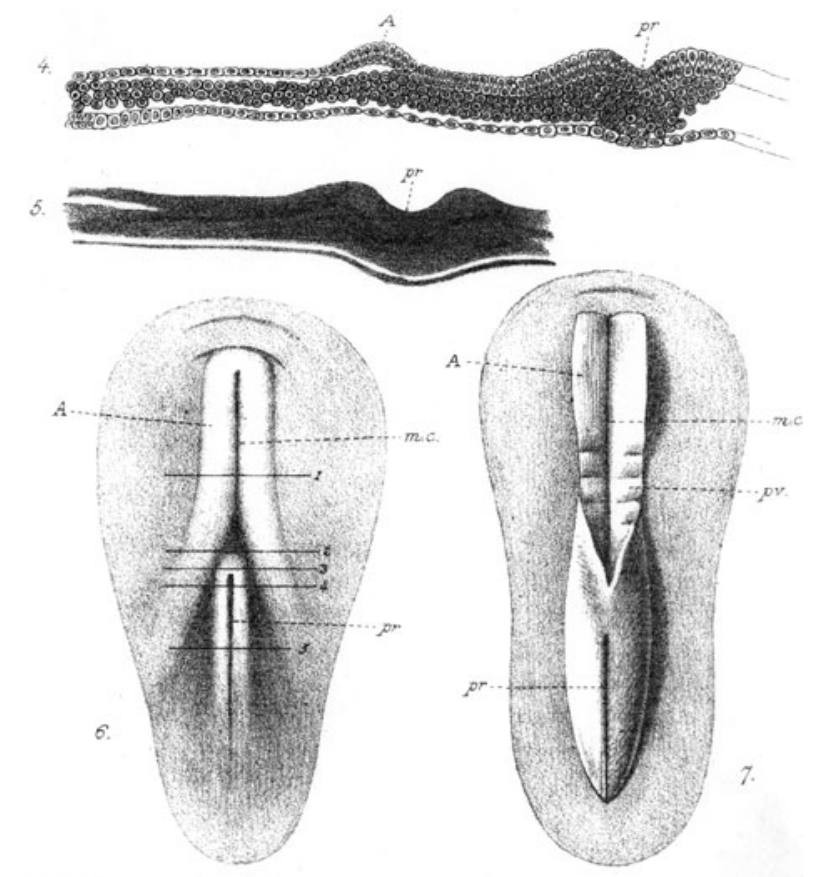

Fig. 7. Chick blastoderm. In sections $\mathbf{( 4 , 5 )}$, the lines 1-5 indicate where the sections were cut in illustration 6; $A$, medullary grooves; pr, primitive groove. (6) 23 hours; m.c., medullary groove. (7) 28 hours; pv, Protovertebratae (from Balfour 1873b, Table XIII). 
Fig. 8. Cleavage of frog egg (Rana esculenta), dorsal view. (A) 1 first cleavage; 2,3 second cleavage; $b$, boundarylayer. (B) The same view; $P$, pit at the pole. (C) Large boundary layer. (D) Scheme of 4th stage cleavage with both boundary layers in parallel areas; the cleavage areas of the dorsal region (full lines) and ventral region (broken lines) strike each other at the boundary surface. (E) 1,2, the 'older' cleavage areas; 3, the 'new' cleavage area; the broken lines indicate the positional change of the areas. (F) Scheme of 8th stage cleavage, dorsal view (from Rauber 1883a, Table XII and Figs. 21-25, 27 therein).

the two structures' (Balfour 1885: 165). Nowadays Balfour is credited with the discovery of the intimate relationship between the avian primitive streak and the blastopore of lower vertebrates (cf. Hall, 2000). However, this claim needs further study penetrating carefully into Balfour's staining experiments and interpretations of his observations before it can be fully accepted.

\section{Enter Cellularmechanik}

In the 1880s Oscar Hertwig (1849-1922) and Kölliker both thought of the germ layers as histologically primitive organs and considered these layers undifferentiated cell complexes (Hertwig 1883; Kölliker 1876). However, Rauber pondered as did Goette and Carl Rabl (1853-1917) whether the germ layers are the product and expression of a more or less advanced differentiation that cleaves the germ into organs by mechanical, chemical and/or physiological forces (Rauber 1883a). When stained germ layers were microscopically analysed the cells forming these layers definitely showed differences in shape and chemical composition. Rauber realized that cells are assigned a specific location in the cellular structure of the embryo by a regulatory cleavage mechanism that assembles the animal body. To construe this behavior he introduced the concept of local signals (Lokalzeichen) being inherent in cells or cell complexes (Rauber 1881: 20-21). In his own words, 'every cell possesses a local signal informing it about its whereabouts' (Rauber 1877b: 46). To learn more about it, he consequently shifted his attention to the relationship between the formation of germ layers and cell specification. Here he followed Remak's work and labelled this property of cellular differentiation and morphogenesis as the genetic principle (Rauber 1883b: 28; cf. Remak 1851).

In a thought experiment Rauber imagined an integrative mechanism of cleavage, which partly employed Lotze's, or His' biomechanics of folding. He also referred to the Swiss botanist and engineer Simon von Schwendener (1829-1919) who studied the growth of fugal hypha and explained the growth mechanisms by a set of orthogonal trajectories. Schwendener distinguished between radial and tangential forces that can effect the inclusion of new substances between the micelles (cells) (Schwendener 1874). The image Schwendener depicted to visualize it, displayed the structure of a 'virtual' cell skeleton. Rauber concluded, therefore, that cells are protoplasmic bodies with a nucleus (which was already accepted knowledge) and a trajectorial 'zoning surface'. The concept of a zoning surface relied on his search for geometrical laws of morphogenesis and his commitment to the regular shapes of crystals.

Based on the cleavage direction he imagined a simple line of cubical cells forming a cell layer on a horizontal plane. Each of these cells would divide into two cells that grow to the same size as the mother cells. If the cleavage direction proceeds along the vertical axis of the cell layer, the cells will elongate; if the cleavage direction goes parallel to the equatorial plane the cells will thicken. Once tensional resistance affects equatorial and vertical axis simultaneously, the cell layer folds or warps. In Rauber's version cell division is produced by a disparity of growth of the cell surface with a volume increase of the whole cell body since the surface expands by the square and the volume by the cubic (Rauber 1876b: 43, 45). He compared this mode of operation to a graph that obeys the laws of geometry as a spiral does (Rauber 1881: 22). In attempting to develop a trajectorial system of cleavage shapes Rauber (1883a) hoped that future research will deduce a cleavage geometry from the (real) contour of an animal body. Figure 8 A-E depicting the fourth cleavage stage of Rana esculenta renders Rauber's mapping of a developing egg by the means of spheric geometry.

This was also the time when Edouard van Beneden (18451910), Oscar Hertwig, Walther Fleming (1843-1905) and Eduard Strassburger (1844-1912) were publishing their work on nuclear division and fertilization. And Rauber?

In a classic article on cell morphology, published in 1883, he asked whether the mechanism that set into motion cleavage patterns, is caused by the canalization of protoplasm, or by a change of the mitotic axes (Rauber 1883a: 239). In a first answer he argued that the orientation of nuclear division, whether corresponding to the equatorial or vertical cell axis, depended first on the cell skeleton the structure of which is determined by the mitotic axis. Conversely, the position of the axis of cell division depends on the form and composition of the protoplasm enveloping it (Rauber 1884: 33). He further theorized that it might be possible that in the sea urchin egg (the favorite model organism of cytogeneticists), the orientation of the first karyokinetic axis and cleavage plane condition each other. In short, Rauber offered a cyto-mechanical model to explain the shaping of the embryo during the early stages of embryogenesis. As a consequence, cell dynamics are triggered by the tension and pressures of differentiating, growing and moving cells inside the germinal disc. A few years later Theodor Boveri proved Rauber's hypothesis correct (Boveri 1901). What Rauber here tentatively formulated in a nutshell, anticipated one of the most fruitful research programs of classical cytogenetics that connected chromosomal behavior to Mendelian genetics.

Moreover, it appears that Rauber was the first to transfer nuclei experimentally. He used two syringes, sucked the nucleus out of a frog and a toad egg and exchanged them shortly after the eggs were fertilized. Of course, such a treatment was too 


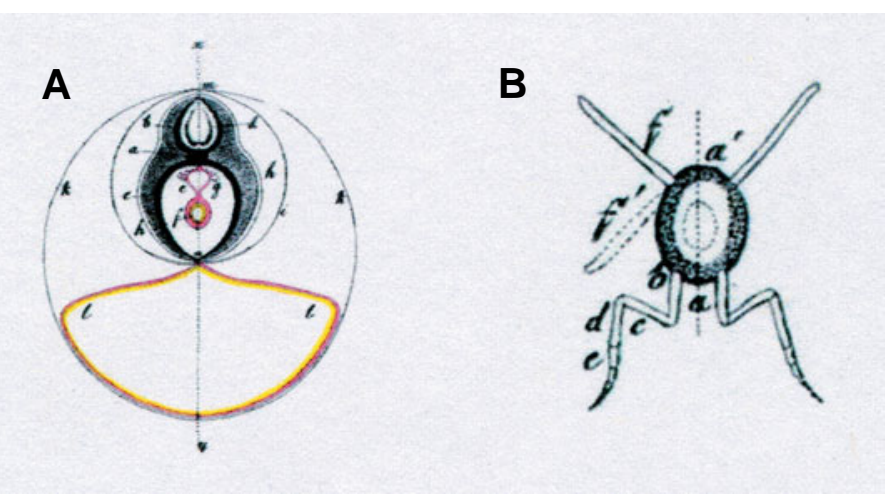

Fig. 9. Idealized schemes of animal bauplan. (A) A vertebrate animal; $a$, spinal column; $b$, dorsal plate; $c$, abdominal layer; $d$, spinal medulla; $e$, vessel duct; $f$, mucuous tube (endoderm); g, mesonephros; h, membrane; i, amnion; $k$, serous layer; l, yolk sac; $m$, crest of dorsal plate. (B) An articulate animal. a, a' longitudinal axis of body segments; b, hip; $c$, femoral; $d$, lower leg; $e$, foot; $f$, wings; $f^{\prime}$, position of a non-developed wing (from Baer 1828, Table III and Figs. 4,8 therein).

crude to give a definitive result. Rauber was a bit frustated, but was convinced that nucleus and cytoplasm together transmit hereditary traits (Rauber 1886; cf. Beetschen and Fischer 2004).

\section{An evolutionary issue}

Von Baer had described the embryogenesis of articulate animals as a evolutiva gemina arising symmetrically from the ventral layer of the embryo, which made the adult animal look as if walking on the back. Then he compared the body of this animal type, regarding its mode of formation, to the ventral tube of vertebrates whereby one should imagine that the ventral tube is located inversely. In his 'reflections' he concluded that the embryonic scheme of articulate animals resembles a half of the number 8 (von Baer 1828: 245, 247; Fig. 9 therein). Further, von Baer stated that vertebrate and articulate animals emerge from the primitive streak and, therefore, share a homologous structure for a short moment during their developmental history (von Baer 1828: 222).

Starting with von Baer's work on the Entwickelungsgeschichte of chicken, pigs, dogs, rabbits and some other animal classes, embryologists studied the pattern of embryogenesis in different species and discovered, for instance, that the medullary grooves of worms, arthropods and vertebrates display homologous formations. Thanks to Rauber's work, comparative embryologists came to know that birds and teleosts develop their primordial embryonic anlage from the posterior marginal zone of the blastodisc. Then Alexander Kowalewsky (1840-1901) demonstrated that the medullary groove of frogs, ascidians and Amphioxus continues the endodermal invagination into the primitive streak/blastocyst (Kowalewsky 1866; Brauckmann and Gilbert 2004).

As already said, Rauber linked the formation of the primitive streak to the blastoporal lips and concluded that the marginal zone in birds and teleosts has the same function as the blastopore (Rauber 1876f: 9). Moreover, he thought of the primitive streak in birds as being homologous to the merged lateral lips of a long, drawn-out blastopore of frog gastrulation (Rauber 1875a). Based on his microscopic observation of cell dynamics and the formation of germ layers Rauber, therefore, concluded that birds pass through a gastrula stage when they form a blastocoel (Rauber 1877a). Thus, the cavity of the Amphioxus blastula is homologous to the blastocoel of a blastodisc. Conversely, the real germinal disc of birds and teleosts is the blastoderm at the gastrula stage (Fig. 10).

In a memorial lecture about von Baer, Rauber discussed the issue of idealistic morphology and the constancy of animal classes. In this discussion he pointed out how to address a specific problem, namely the development of the central nervous system of metazoans with a phylogenetic approach to comparative embryology (Baer 1828: 247-249 and 1873; Rauber 1877b). Three years earlier Louis Agassiz (1807-1873), a student of Cuvier, welcomed Baer's harsh criticism of the Darwinian, or better, Huxleyan homology between Ascidians and vertebrates (Agassiz 1874). The dispute pointed to the crucial question whether vertebrates or their progenitors originated from arthropods. If they did, such ancestors would have carried their backbones on the ventral side of the body. Some decades earlier, Etienne Geoffroy St. Hilaire (1772-1844) already had formulated it in a more diplomatic way by calling insects "vertebrates walking on their back", which identified the ventral side of articulate animals with the dorsal side of vertebrates. Modern developmental genetics confirms Geoffroy St.-Hilaire's interpretation that an inversion of the dorsoventral axis leads from arthropods to vertebrates and proposes, in reference to Haeckel's gastraea, a hypothetical ancestral animal (cf. De Robertis and Sasai 1996: 40).

Rauber was more sympathetic with Geoffroy St.-Hilaire's statement of the single plan from which all animal forms could be derived than with Cuvier's four (arche)types (Cuvier 1817; Geoffroy St.-Hilaire 1822). Therefore, he reinterpreted Cuvier's and von Baer's type doctrine and claimed that the constancy of types means correspondence, or homology of the Bauplan. Then he corrected Baer's statements on the vertebrate ancestor, demonstrating that adult vertebrates differ from arthropods by a dorsal rotation around the lateral axis of the embryo during neurulation (Fig. 11). Thereby and supported by an ingrowth of the anterior and dorsal plate the vertebral nervous system attains to the dorsal body region. As articulate animals do not have such a mode of development, their homologous organs are located on the ventral body side. Thus, the annelids' brain corresponds morphologically to the vertebrate medulla (Rauber 1877b). In regard to the
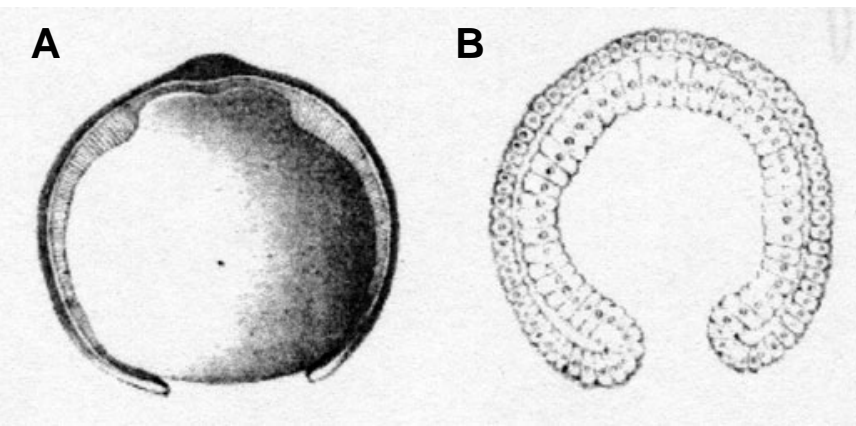

Fig. 10. Gastrulae schemes. (A) Duck egg; ectodermal overgrowth of the endoderm and entodermal overgrowth of the yolk sphere. (B) Amphioxus after Kowalewsky (from Rauber 1876d, Table I/ and Figs. 28, 29 therein). 
formation of the blastopore and primitive streak, the different topologies of the central nervous systems bear on how the blastocoel is pushed to the dorsal surface of the germ. When looking to the germ layers, the difference rests on the fact that these layers transform into the ventral surface of the germ. In extending his phylogenetic reasoning Rauber concluded that the medullary grooves of annelids, arthropods and vertebrates are homologous structures (Rauber 1877b: 7).

These 'phylogenetic' discoveries became possible once one began to focus on the egg yolk and the way the yolk deforms the blastodisc, instead of looking to the differences in cleavage patterns. The paradigm shift helped comparative embryology to arrive at a common pattern shared by many, maybe all species, like the two-layered planula or gastrula (Rauber 1876b; Brauckmann and Gilbert 2004). However, as Rauber complained, nobody ever cared for the question "why". In other words, comparative embryology was not yet willing to apply consequently the phylogenetic principle to explain embryological phenomena and analyzing observational data. The only exception was Haeckel who furnished Darwin's evolutionary theory with the embryonic
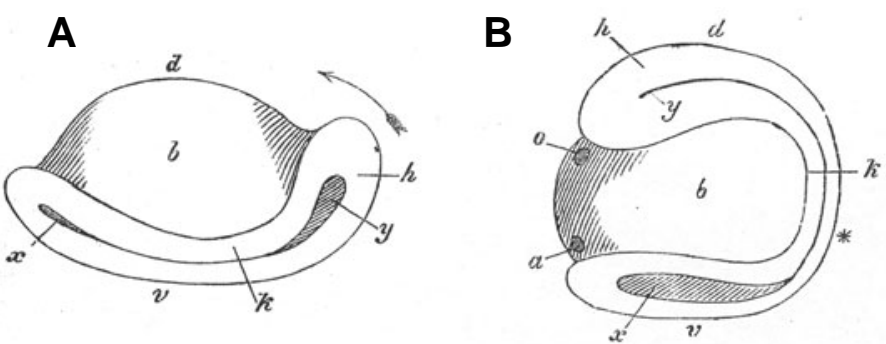

Fig. 11. Homology by axis rotation. (A) Planarian embryo; $a$, anus; $b$, blastoderm; d, dorsal side; $h$, brain; $k$, germ layers; $v$, ventral side; $x, y$, posterior and anterior side of primitive streak. (B) Vertebrate embryo (from Rauber 1877a: 17, Figs. 6-7 therein).

data of Kowalewsky (Rauber 1877b).

Therefore, Rauber emphasized the importance of a comparative study of Entwickelungsgeschichte to disclose whether and to what extent, homology influences the embryogenesis of different species (in sensuHaeckel's gastraea principle) (Rauber 1875a). In his approach evolution and development appear to be bound together like effect and cause. Although he did not elucidate whether development directs evolution, or evolution causes developmental forms in detail, he apparently thought of evolution as the causal factor for morphogenesis (Rauber 1876f).

\section{Conclusion}

In chick gastrulation Rauber observed that the mesoderm initiates the differentiation of endoderm and ectoderm and finally forms a complete blastodisc. He further showed that the endoderm consists of a one-layer membrane of flattened cells and differentiates earlier than the ectoderm, which folds over the subjacent cell mass. Like Haeckel, Rauber explained the occurrence of the first embryonic anlage in the dorsal end of the germinal disc of birds and fishes phylogenetically and stated that it rested on the homologous relationship between primitive streak and blastopore.

Besides the discovery of the formation of the primitive streak and its homology to the blastopore, Rauber utilized a mechanical approach towards developmental questions before Roux demanded it (Brauckmann 1999). For Rauber, the form of the developing embryo determines the arrangement of the cell walls (membranes), comparable to a physiology of sculpturing and triggered by local signals inside the cell (Rauber 1886). By it, Rauber implicitly agreed to Baer's notion of epigenetics claiming that each developmental process necessarily results from a preceding stage and, at the same time, constrains a succeeding one. In his theory, morphogenesis proceeds by cell proliferation, by cell growth resulting in changes of cell morphology, by cell locomotion and cell differentiation and all these processes are ordered in space and time. However, he openly conceded that embryology and histology could not yet explain cell division until one had reduced the process to chemo-physical laws and come to an understanding as to know the timing mechanism of gastrulation (Rauber 1883).

In general, Rauber's objective was to explore whether morphogenetic changes are merely functional, produced by cell growth, or whether they are purely geometrical depending on law-like growth relations. To conduct such a research program he formulated a Cellularmechanik intending to explain the forces and potentials of morphogenesis and including heredity. However, his methodologic preconception of a purely biomechanical approach prevented him from applying physiology to embryogenesis as Wilhelm Roux postulated in his Entwickelungsmechanik (Mocek 1998: 229). Ironically, Rauber was caught in the same 'anatomical' cage as His. Nevertheless, August Rauber was one of the first biologists of the 19th century who experimentally perturned developing eggs for causally deducing the mechanisms of early embryogenesis.

\section{Acknowledgments}

The paper is a revised and enlarged version of the Rauber Lecture delivered at the Tissue Culture Conference VI at the University of Tartu School of Medicine on September 23, 2005. I am grateful to Andres Arend for his invitation. To Susanne Stangl who helped to find some Rauber articles in the Obersteiner Library (Vienna) and to Ken Kalling for the Rauber photo and some illustrations I owe special thanks. The discussions with John M. Opitz and Gary C. Schoenwolf helped to improve the manuscript as did severalsuggestions by the anonymous referees. All the errors belong to the author.

\section{References}

AGASSIZ, L. (1874). Evolution and Permanence of Type. The Atlantic Monthly35: 92-101.

AUNAPPU, M., PUUSUEPP, M., TOOMSALU, M. and AREND, A. (2005). Tartu Old Anatomical Theatre 200-Contribution of German Anatomist. Ann. Anat. 187: 415-420.

BAER, K. E.v. (1828/1837). ÜberEntwickelungsgeschichte der Thiere. Beobachtung und Reflexion, Bde. 2, Borntraeger, Königsberg.

BAER, K. E. v. (1873). Entwickelt sich die Larve der einfachen Ascidien in der ersten Zeit nach dem Typus der Wirbel=thiere. Mem. Acad. Imp. Sci. St. Petersburg 19(8): 1-35.

BALFOUR, F. R. (1873a). The development and growth of the layers of the blastoderm. Quart. J. Microsc. Sci. 13: 266-276.

BALFOUR, F. R. (1873b). On the disapperance of the primitive groove in the embryo chick. Qart. J. Microsc. Sc. 13: 276-280.

BALFOUR, F. R. (1880/1885). A Treatise on Comparative Embryology, vol. II. 2nd ed. (without alterations from the first edition). London. Macmillan \& Co. 
BEETSCHEN, J.-Cl. and FISCHER, J.-L. (2004). Yves Delage (1854-1920) as a forerunner of modern nuclear transfer experiments, Int. J. Dev. Biol. 48: 607612.

BOVERI, T. (1901). Die Polarität von Oocyte: Ei und Larve des Strongylocentrotus lividus. Zool. Jahrb. Abt. Anat. Ontol. 14: 630-653.

BRAUCKMANN, S. (1999). A history of causal morphology: Reinhard Mocek's "Die werdende Form" (Essay review). Am. J. Med. Gen. 87: 281-285.

BRAUCKMANN, S. and Gilbert, S. F. (2004). "Sucking in the gut": A brief history of early studies on gastrulation. In Stern, C. D. ed. Gastrulation: From Cell to Embryo, Cold Spring Harbor Laboratories Press, Cold Spring Harbor, NY, pp. $1-20$.

CALLEBAUT, M. (2005). Origin, fate and function of the components of the avian germ disc region and early blastoderm: Role of ooplasmic determinants. Dev. Dyn 233: 1194-1216.

CALLEBAUT, M. and VAN NUETEN, E. (1994). Rauber's (Koller's) sickle: the early gastrulation organizer of the avian blastoderm. Europ. J. Morph. 32: 35-48.

CHURCHILL, F. B. (1991). The rise of classical descriptive embryology. In Gilbert, S. F. (ed.) A Conceptual History of Modern Embryology, Plenum Press, New York, pp. 1-29.

CUVIER, G. (1817). Le règne animal, distribué d'après son organisation, tôme 1, Deterville, Paris.

DE ROBERTIS, E. M. and SASAI, Y. (1996). A common plan for dorsoventral patterning in Bilateria, Nature 370: 37-40.

DURSY, E. (1866). Der Primitivstreif des Hühnchen. Schauenburg, Lahr

GEOFFROY St. HILAIRE, E. (1822). Considérations générales sur la vertèbre. Mém. Mus. Hist. Nat. 9: 89-119.

GILBERT, S. F., OPITZ, J. M. and RAFF, R. A. (1996) Resynthesizing evolutionary and developmental biology. Dev. Biol. 173: 357-372.

GOETTE, A. (1875). Die Entwickelungsgeschichte der Unke (Bombinator igneus) als Grundlage einer vergleichenden Morphologie der Wirbelthiere, Leopold Voss, Leipzig.

GURWITSCH, A.G. (1922). Über den Begriff des embryonalen Feldes. W. Roux's Arch. Entw. Mech. Org. 51: 388-415.

HALL, B.M. (2000). Balfour, Garstang and de Beer: The first century of evolutionary embryology. Amer. Zool. 40: 718-728.

HAMBURGER, V. and HAMILTON, H. L. (1951/1992). A series of normal stages in the development of the chick embryo. J. Morphol. 88: 49-92. [reprinted in (1992). Dev. Dyn. 195: 231-272.]

HERTWIG, O. (1883). Die Entwicklung des mittleren Keimblattes der Wirbelthiere. Studien zur Blättertheorie, Bd. V., G. Fischer, Jena.

HIS, W. (1870). Ueber die Bedeutung der Entwickelungsgeschichte für die Auffassung der organischen Natur: Rectoratsrede, gehalten am 4. November 1869, Vogel, Leipzig.

HIS, W. (1874). Unsere Körperform und das physiologische Problem ihrer Entstehung. Briefe an einen befreundeten Naturforscher, Vogel, Leipzig.

HIS, W. (1875). Berichtigung. Centralblatt für die medicinischen Wissenschaften 13(19): 304.

HIS, W. (1877). Neue Untersuchungen über die Entwicklung des Huehnchens. Arch. Anat. Physiol. 1: 112-187.

HOPWOOD, N. (1999). "Giving body to embryos". Modeling, mechanism and the microtome in late nineteenth-century anatomy. IS/S 90: 462-496.

KOGERMAN-LEPP, E. (1991). August Rauber - an outstanding scientist-anatomist. A. Rauberi mälestuskonverents 150 aastat sünnist. Tartu 19.-21. Sept. 1991, Tartu Ülikool, Tartu, pp. 5-11.

KÖLLIKER R. A. v. (1861). Entwickelungsgeschichte des Menschen und der höheren Thiere, Wilhelm Engelmann, Leipzig.

KOWALEWSKY, A. (1866). Entwickelungsgeschichte der einfachen Ascidien. Mém. Acad. Imp. Sci. St. Petersburg. VII Série. Tome X.

KROOS, J. (1994). The Czar's Madman, New Directions Publishing Co., New York.

LANKESTER, R. F. (1873). On the primitive cell layers of the embryo as the basis of genealogical classification of animals and on the origins of vascular and lymphs systems. Ann. Mag. Nat. Hist. 11: 321-328.

LAWSON, A. and SCHOENWOLF, G. C. (2003). Epiblast and primitive-streak origins of the endoderm in the gastrulating chick embryo. Dev. 130: 3491-3501.

LUBOSCH, W. (1924). August Rauber. Sein Leben und seine Werke. Anat. Anz. 58: 129-138, 142-148, 170-172.

LOTZE, R. H. (1843/1885). Leben. Lebenskraft. In: Handwörterbuch der Physiologie, hg. Rudolf Wagner, Bd. 1, Braunschweig 1842, S. IX-LVII (Neudruck: Kleine Schriften, hrsg. v. David Peipers, Leipzig 1885, pp. 139-220.)

MOCEK, R. (1998). Die werdende Form. Eine Geschichte der kausalen Form, Acta Biohistorica. Schriften aus dem Museum und Forschungsarchiv für die Geschichte der Biologie, Bd. 3, hrsg. von Armin Geus, Basilisken Presse, Marburg an der Lahn.

NYHART, L. K. (1995). Biology Takes Form. Animal Morphology and the German Universities, 1800-1900, University of Chicago Press, Chicago.

OPPENHEIMER, J. M. (1940). The non-specificity of the germ layers. Quart. Rev. Biol. 15: 1-27.

PANDER, C.H. (1817). Beiträge zur Entwicklungsgeschichte des Hühnchens im Eye, Brönner, Würzburg.

PAWLOW, V. (1991). Zum 150. Geburtstag des Anatomen August Rauber (18411917). Z. ärztl. Fortbildg. 85: 591-593.

RAUBER, A. (1875a). Beiträge zur Keimblätterbildung bei den Wirbeltieren. Sitzungsberichte der Naturforschenden Gesellschaft zu Leipzig 7: 65-68

RAUBER, A. (1875b). Über die embryonale Anlage des Hühnchens. 2. Teil. Die Gastrula des Hühnerkeims. Centralblatt für die medicinischen Wissenschaften 13(4): 49-52.

RAUBER, A. (1876a). Über die Stellung des Hühnchens im Entwicklungsplan, Engelmann, Leipzig.

RAUBER, A. (1876b). Über Variabilität der Entwicklung. Sitzungsberichte der Naturforschenden Gesellschaft zu Leipzig 3: 39-46.

RAUBER, A. (1876c). Über die Bedeutung Panders in der Entwickelungsgeschichte. Sitzungsberichte der Naturforschenden Gesellschaft zu Leipzig 8: 129-133.

RAUBER A. (1876d). Primitivrinne und Urmund. Gegenbaurs Morphol. Jb. 2: 550574.

RAUBER, A. (1876e). Zur Aufklärung. Centralblatt für die medicinischen Wissenschaften 14(14): 256

RAUBER, A. (1876f). Über die erste Entwicklung der Vögel und die Bedeutung der Primitivrinne. Sitzungsberichte der Naturforschenden Gesellschaft zu Leipzig. 8: 8-9

RAUBER, A. (1876g). Elastizität und Festigkeit der Knochen, Engelmann, Leipzig

RAUBER, A. (1877a). Primitivstreifen und Neurula der Wirbeltiere, Engelmann, Leipzig.

RAUBER, A. (1877b). Dem Gedächtnis K. E. v. Baer. Nervencentra der Gliederthiere. Sitzungsberichte der Naturforschenden Gesellschaft zu Leipzig 9: 1-19.

RAUBER, A. (1879/1880). Formbildung und Formstörung in der Entwicklung von Wirbelthieren Gegenbaurs, Morphol. Jb. 5: 661-701; 6: 1-48; 6: 129-184.

RAUBER, A. (1881). Über die Grundform und den Begriff der Zelle. Sitzungsberichte der Naturforschenden Gesellschaft zu Leipzig 8: 19-22.

RAUBER, A. (1883a). Neue Grundlegungen zur Kenntnis der Zelle. Gegenbaurs Morphol. Jb. 8: 233-338.

RAUBER, A. (1883b). Über die Entwicklung der Gewebe des Säugetierkörpers und die histologischen Systeme. Sitzungsberichte derNaturforschenden Gesellschaft zu Leipzig 10: 13-38.

RAUBER, A. (1884). Über den Einfluss der Schwerkraft auf die Zellteilung und das Wachstum. Sitzungsberichte derNaturforschenden Gesel/schaft zu Leipzig11: 30-36.

RAUBER, A. (1886). Personaltheil und Germinaltheil des Individuum. Zool. Anz. 9: $166-171$.

RAUBER, A. and KOPSCH, F. (1886/1998). Anatomie des Menschen, 4 vols., G. Thieme, Stuttgart.

REMAK, R. (1850 - 1855). Untersuchungen überdie Entwickelung der Wirbelthiere, G. Reimer, Berlin.

ROUX, W. (1889). Die Entwicklungsmechanik der Organismen - eine anatomische Wissenschaft der Zukunft. Festrede, Wien.

SANDER, K. and SCHMIDT-OTT, U. (2004). Evo-Devo aspects of classical and molecular data in a historical perspective. J. Exp. Zool. 302B: 69-91. 
SCHMITT, S. (2005). From eggs to fossils: Epigenesis and transformation of species in Pander's biology. Int. J. Dev. Biol. 49:1-8.

SCHWENDENER, S. v. (1874). Das mechanische Prinzip im anatomischen Bau der Monocyteleen, Engelmann, Leipzig.

SCHWENDENER, S. v. (1881). Über die durch Wachsthum bedingte Verschiebung kleinster Theilchen in trajectorischen Curven. Monatsberichte der KöniglichPreussischen Akademie der Wissenschaften 27: 408-433.

TAMMIKSAAR, E. and BRAUCKMANN, S. (2004). Karl Ernst von Baer's "Über Entwickelungsgeschichte der Thiere". Bd. II. Hist. Phil. Life Sci. 26: 291-308.
THOMPSON, D'Arcy W. (1942). On Growth and Form, Cambridge University Press, Cambridge.

Received: November 2005

Reviewed by Referees: December 2005

Modified by Authors and Accepted for Publication: February 2006

Published Online: March 2006 